team at Oxford when I am introduced before a lecture as "the man who gave the first injection of penicillin." When this happens I think with gratitude of that quiet moment in the ward at the Radcliffe Infirmary with Florey and Witts, to both of whom I owe so much, standing by and I think of Mrs Elva Akers offering me her vein for the injection.

\section{References}

1 Chain E, Florey HW, Gardner AD, at al. Penicillin as a chemotherapeutic agent. Lancel

1940;ii:226-8.

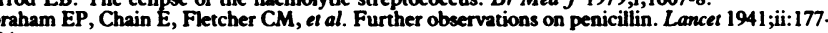

5 Macfarlane G. Alexander Fleming: the man and the myth. London: Chatto \& Windus, 1984:245-60.

\title{
Penicillin: early trials in war casualties
}

\author{
SIR IAN FRASER
}

About 40 years ago the trials of penicillin on war casualties in the forward area began. The original team consisted of a surgeon and a bacteriologist. The surgeon (IF) had to be old enough to have had some experience of the failure of the sulphonamides and other antiseptic drugs, but young enough to be able to wade ashore if necessary during the various invasions. Probably more important was the choice of an expert bacteriologist, Major Scott-Thompson, later professor of bacteriology in Cardiff. The team was under the overall control of the Medical Research Council and the Royal Army Medical Corps.

The trials could not have been sooner, because in Britain penicillin was in such short supply, so when the time came all the penicillin in Oxford was needed. What there was was mostly in the form of calcium salt suitable only as a surface dressing and perhaps enough for 100 patients, while of the sodium salt suitable for injection there was enough for only two or three dozen patients.

Serendipidity seems to have accompanied penicillin in all its stages right from the accidental discovery by Alexander Fleming in 1928 of a fungus of incredible rarity. Ten years later at Oxford Florey decided to try to extract pure penicillin from "the broth" and produce something that could be of real clinical value. A Jewish evacuee, Ernst Chain, had been working with him for some time; he was a man with an international reputation in the study of enzymes. Together they formed a useful partnership. A further piece of luck was the choice of the mouse as the laboratory research animal: had they chosen the guinea pig it might have been quite a different story. Another piece of good fortune was that Florey had as his partner in the clinical trials Hugh Cairns, a neurosurgeon. Neurosurgery was ideal for the experiment, for in abdominal surgery there were many highly resistant organisms, which might have delayed the progress in this research. Fleming had put penicillin on the map, but Florey really put it on the market. Those of us involved in the early stages of this work could sense the tension at times in the relationship between these two great men.

The timing of the experiment was, as far as the war was concerned, also important. Penicillin became available just at the end of the eighth army desert campaign (February 1943) and was therefore in full swing and ready for use by the first army for the invasion of Sicily and Italy when the attack took place through the "soft underbelly of the Axis."

Our team was given a two week crash course in Oxford, when we saw the drug being produced and were taught the methods of using it as well as how to organise a mobile laboratory in the forward area. We worked with Florey at close quarters. He had turned his university department almost into a factory. Mrs Ethel Florey was busy on her bicycle each day, collecting the overnight urine from the various hospitals from patients taking parenteral

Sir Ian Fraser, 35 Wellington Park, Belfast BT9 6TN.

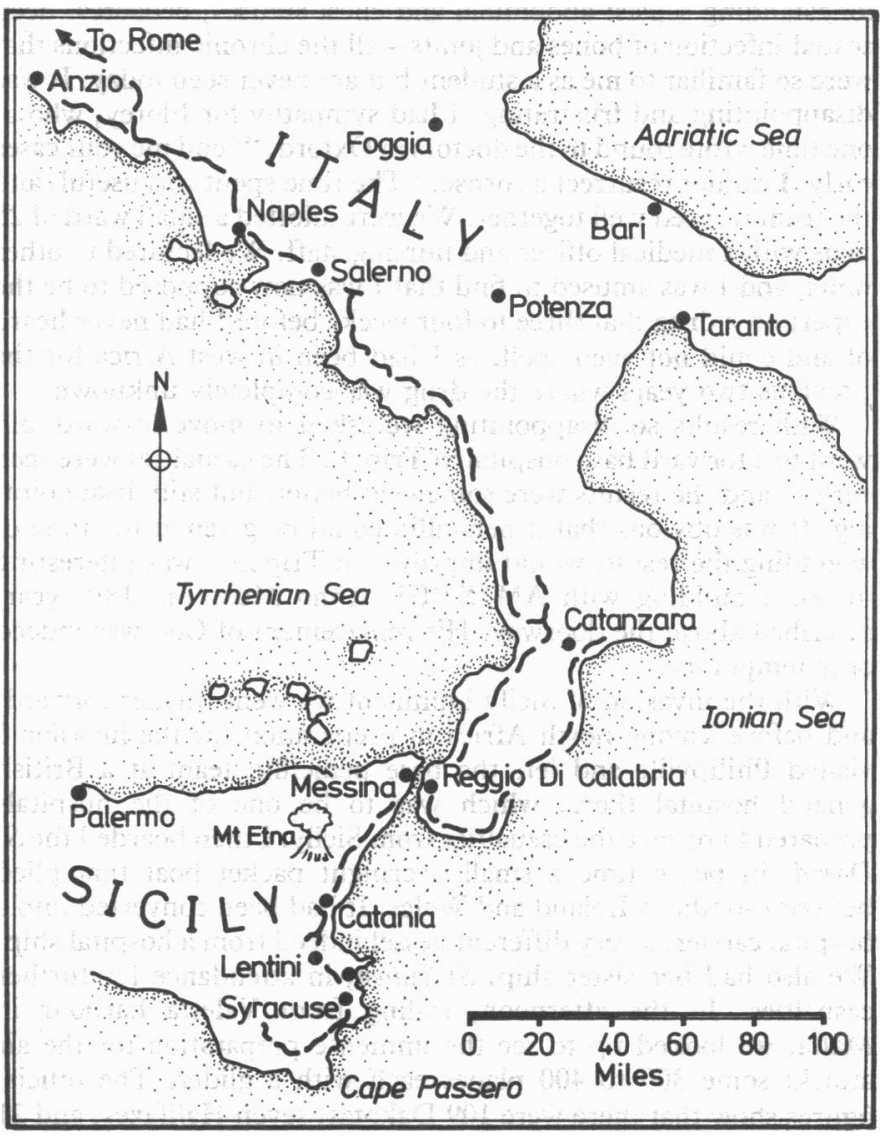

penicillin. The more sophisticated among us called this "the morning milk round," the less so called it "the P patrol." This urine contained two thirds of what had been given to the patient, and of this one half could be retrieved-recycling, so to speak. One great advantage was that this penicillin retrieved from the urine had been freed from the "gubbins" of the culture medium, which was some $90 \%$ of the total that the patient had received at the time of the original injection. This purified penicillin was very popular as its injection was virtually painless and free from the short but awful reaction that the impure penicillin produced. At that time penicillin was a brown powder and in solution it looked rather like dilute mustard, and when injected it felt like it too.

The penicillin research team were given instructions not to try the drug out on diseases that had already been fully researchedfor instance, osteomyelitis, malignant endocarditis, venereal disease - or indeed on enemy casualties. The embargo on venereal disease I readily agreed to as it is not a disease one acquires normally when wading ashore on foreign soil. I did, however, 
refuse to accept the embargo on enemy casualties. I said that this must be left to my own personal clinical judgment.

England in the middle of a war could not hope to produce in quantity a drug that required such equipment as large fermentation vats. Imperial Chemical Industries would perhaps have been the only firm to have tackled the job. It was reluctantly felt that it must be passed over to the Americans. Florey has been unfairly blamed at times for "giving it to the Americans on a plate." America, however, was not yet in the war, though it did get involved only a short time later.

\section{First foreign experiences}

The team was first sent to north Africa. We went to a base hospital in Algiers to be attached to one of the four very large hospitals in that area. We sailed out on a small hospital ship, the Newfoundland, which was later sunk.

The work in Algiers was disappointing. The cases were all of longstanding sepsis: abdominal and chest sinuses, bedsores, deep seated infection of bones and joints-all the chronic infections that were so familiar to me as a student but are never seen today. It was disappointing and frustrating. I had sympathy for Florey, who at one time wrote round to the doctors in Oxford, "Send me your cases early, I cannot resurrect a corpse." The time spent was useful, and the team worked well together. We were allotted a small ward of 25 beds with a medical officer and nursing staff. We lectured to other units, and I was amused to find that I was now supposed to be the expert on a drug that three to four weeks before I had never heard of and could not even spell, as I had been in west Africa for the previous two years where the drug was completely unknown.

With results so disappointing we asked to move forward and went to a forward base hospital in Tripoli. The casualties were seen earlier, and the results were somewhat better, but still disappointing. It was obvious that if penicillin could be given at the time of wounding the results would improve. In Tripoli it was interesting to see a building with AM XVIII (Anno Mussolini 18th year) inscribed above the doorway. His replacement of God was indeed only temporary.

With the invasion of Sicily imminent we went further forward, and before leaving north Africa in preparation for the invasion I visited Philipville and left the base penicillin team at a British general hospital there, which was to be one of the hospitals prepared to receive the casualties from Sicily. I then boarded the $S t$ David, in peace time a small overnight packet boat that plied between southern Ireland and Wales. It had been converted into a hospital carrier, a very different vessel indeed from a hospital ship. We also had her sister ship, St Fulien, in attendance for further casualties. In the afternoon, sailing from Valetta harbour in Malta, we looked up to see the immense preparation for the air attack: some 300 to 400 planes each with a glider. The official figures show that there were 109 Dakotas, seven Halifaxes, and 21 Albermarles (RAF). Behind these were 129 Waco gliders and eight Horsa gliders. The Horsa could carry $32 \mathrm{men}$, the Waco had a maximum of 18 , or only four if it carried a jeep as well. Many of these were lost as the gliders were sometimes released more than a mile from the shore, and with bad weather and high winds they were carried out to sea. The sky was black with planes. I felt for the first time that success was inevitable.

I did not know when I looked up that in one of those gliders was a recent house surgeon of my own who was dropped too far out and never managed to reach the shore.

At dawn the ship reached the south eastern point of Sicily in the region of Cape Passero. We actually went ashore on Sugar Beach and had to wade quite a distance from the launch as we were afraid of fouling its propellers. Meanwhile the St David had moved five miles out, as is usual, so that it could put up its lights. The Sugar Beach casualties were initially very light; in fact our only problem was that the beach was mined and every time we got caught in barbed wire we wondered what was attached to the other end. There was an interesting competition between ourselves and the enemy: they kept dropping flares to light us up and we kept putting up a smoke screen to hide our movements. Later, however, the bombing increased and we had severe casualties. The sea was rough, and transport back on the launches was very painful for the wounded, for with no lights and a smoke screen we had great difficulty in finding the $S t$ David. It sometimes took two and a half hours of searching. The wounded were mostly Canadian, British Royal Marine commandos, and Italians; our airborne troops had landed nearer the centre of the island.

On board the carrier conditions were fairly good. Resuscitation facilities were exceptional with oxygen and plasma laid on for every bed. This department worked flat out the whole time. We had army nursing sisters on board, who were invaluable. The carrier had originally been intended to be used only as an overnight

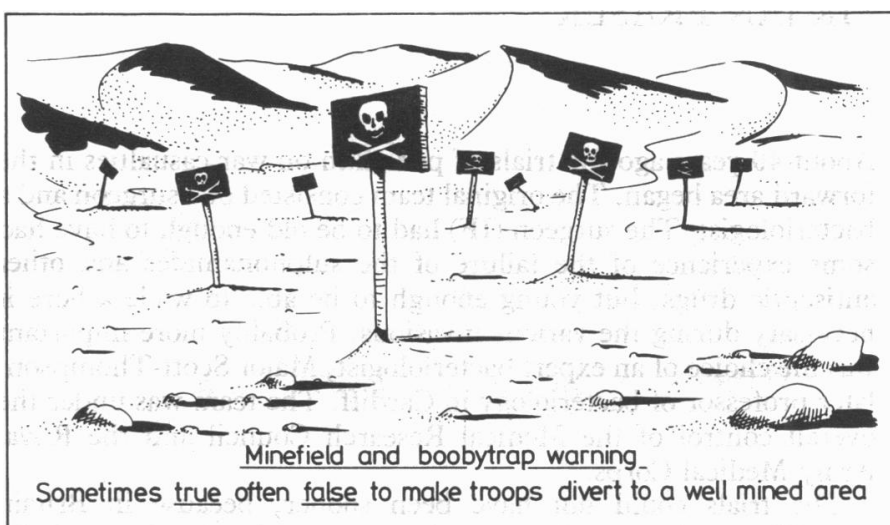

operating theatre to bring the casualties straight back to north Africa. In fact we operated continuously on severe casualties for up to 54 hours. During this time, with the aid of a graded surgeon, some 46 operations were performed. Ninety six pints of plasma had been supplied but no blood. This was unfortunate. One naval commando with both legs shattered did not respond to five pints of plasma and only recovered when given fresh blood from one of the surgical team. This undoubtedly saved his life and he made a good recovery. Some of the patients reached the ship in a poor state after a rough trip in flat bottomed boats that rose on the waves and then came down with a slap on the surface of the water. These casualties should have been retained in a local bivouac ashore. Resuscitation failed in two cases, one of gross retroperitoneal haemorrhage, the other a spinal injury with leaking cerebrospinal fluid. On the other hand a patient with a ruptured spleen with the abdominal cavity filled with blood made a remarkably good recovery. We had 154 patients on the ship, five of whom died. Three quarters of the injuries were the result of bullet wounds. This is usual when the fighting is at close quarters, as in all beach landings. Mortar bombs, booby traps, mines, and hand grenades accounted for the other quarter. Five per cent of the wounds were to the head and neck, $22 \%$ to the body and trunk, $34 \%$ to the arms and shoulders, and $39 \%$ to the legs. There were also some accidental injuries. This is probably typical of a night raid, where it is difficult to differentiate between friend and foe. There were two cases of mental breakdown due to strain, one of which was almost uncontrollable, and two men had eye injuries, losing one eye each. It was frustrating to have no blood on board, and the authorities took a long time to realise how necessary fresh blood was. We had started the war with the idea that plasma was almost as good. It required a full scale confrontation in the desert between Sir Lionel Whitby and Colonel Gladwyn Buttle before the absolute necessity for pure blood was established. The meeting between these great men is still remembered by many of us in the eighth army who were solidly behind Buttle. Plasma had made a reputation for itself in the Spanish Civil War and also in the "phoney war" in Britain, when town bombing led to bricks and mortar injuries and shock without necessarily much external blood loss; for these cases plasma was indeed excellent. 
When I brought the patients back Florey was on the docks with the anxious air of an expectant father. Shortly before this Major General W H Ogilvie (later Sir Heneage) had complained that penicillin cases were getting extra special care. As the man in charge I proudly agreed with this. He was disappointed and perhaps somewhat annoyed that his sulphonamide programme had been superseded, as he had worked out a scheme that gave the wounded soldier a fairly constant concentration of blood sulphonamide, while the penicillin blood concentration had to be renewed every three hours. He suggested that the forward surgeon might have preferred something less difficult and less exacting. It was true that keeping the concentration of penicillin in the blood high was "like filling the bath with the plug out."

\section{Back to the front}

The second visit to Sicily on 27 July 1943 was a more organised affair. I went with Major McLennan who commanded the fifth mobile bacteriological laboratory. He took a special interest in the anaerobes. We left Scott-Thompson at the 48th general hospital in Tripoli, where he would study the bacteriology of the wounds when the patients arrived in north Africa, and with him was Lieutenant Colonel Jim Jeffrey, who would carry out the final surgical steps-such as secondary suturing, skin grafting, closure of amputation stumps. With three different casualty clearing stations, each with a well trained experienced surgeon and several field surgical units, I had no operations to do and so merely asked permission to treat suitable cases with penicillin. The casualties were much as before. Most were caused by road mines, mortar bombs, $\mathrm{S}$ mines, and high explosives, with some sniping and machine gun wounds. Civilian casualties, often children who had walked on mines, formed a distressing part of the work. The vineyards contained magnificent blue grapes; several men lost a foot before it became generally known that the vineyards were minefields.

We confined our research to British casualties, as Americans, Canadians, and prisoners of war were likely to be lost in the follow up. The results were magnificent with clean wounds ready for definitive surgery on arrival at the forward base hospitals. A letter to me from "Pon" D'Abreu (later Professor A L D'Abreu) said, "What the hell are you doing? We have never seen the like of this before." This was praise indeed as it came from one of the most experienced of the eighth army surgeons. We hoped that our patients might all get back to the mainland hospital, but evacuation rested with the whim of the Admiralty. Thus although all cases were clearly marked for Tripoli, some went to other ports in north Africa, some to Malta, and some even to the Nile delta. It was tragic that often the worst wounded, injured by heavy mortar bombs and long distance shelling, had the longest journey to make before reaching us. Often the gunshot wound cases were less seriously ill and arrived much sooner at the casualty clearing stations. It was interesting to see the small Italian children, within a few days of our arrival, wearing neat jackets and suits made out of the expensive nylon parachutes that we had failed to retrieve in time. For a night landing these parachutes were made of beautiful dark green nylon with a pattern of ivy. I am told that the army sisters were also able to make elegant night dresses out of the white nylon parachutes used for daylight work: I naturally have no personal proof of this.

The work was much as before, but on meeting the Americans I was horrified to find that they now had a large quantity of penicillin-much more than ourselves. We were still largely restricted to the calcium sort for surface application only. I stayed in Sicily until the island was finally captured and all resistance had ceased.

With Sicily fully conquered it was felt that the attack on Italy should start as soon as possible. This was to be across the Straits of Messina, where Sicily is separated from Italy by a very narrow strip of water not much wider than the Thames. We could easily see the completely empty beaches as we looked across, and our paratroops, who had dropped the night before, confirmed that they were deserted, as did air reconnaissance.

The invasion was like a bank holiday spree. Reggio di Calabria, the town opposite Messina, was entirely empty. People had fled and had not even closed the doors of their houses. We could go in almost anywhere. Highland division soldiers danced down the main street with parasols and fancy dress "borrowed" from some of the houses. It was a pleasant contrast to the other expeditions and a welcome one. I picked up a small round object slightly larger than a hen's egg from the road. It turned out to be the ivory head, broken off at the neck, of a small figurine of Mussolini, which the owner must have thrown out of an upstairs window. It had been "rejected" and now sits as a paperweight on my desk.

A serious, non-medical army decision now had to be made. Should the army slowly advance from here towards Rome, which was the objective, or would it be quicker to make another landing further up the west coast and so save considerable time? This was the reason for the landing at Salerno. Our landing was not a surprise, and the early fighting was very severe. Even after we had gained a footing we still had not full control. In the hills above the town there were caves in which the enemy had set railway lines with heavy guns. The guns came out to the mouth of the cave, shelled the town, and then withdrew deep into the mountain. It was an interesting sight at night to see our naval guns sending over red hot shells, but although they peppered and pounded the mountainside the final success came only after we sent up some Gurkhas in the darkness with their kukris. I went in fairly early on with five men. All young, 20 or so, in khaki with no rank or regimental badges. They were "conscientious objectors." I hate those words. They were Quakers with a conscience going to clear the minefields; they were willing to be killed but not to take life. I have always admired the Quakers but never more than on that occasion.

\section{Closing scenes}

The struggle at Salerno was long and tedious, but it was vital that it should not fall to the enemy as it would open the road to Rome. While we were working up the west coast General Montgomery's army was advancing up the east coast. I did not see the end of that campaign as I suddenly went down with diphtheria. I had a short period of isolation in a cowherd's hut, then I was flown to Catania to come under the care of Max Rosenheim. Evacuation was interesting but not comfortable. I was suspended on a stretcher from the ceiling of a small aircraft; the plane had no doors as it had been used for dropping paratroops, and was very cold because the blankets kept blowing away.

The penicillin saga ends here. Jim Jeffrey took over from me, but by then the amount of penicillin available was rapidly increasing, and soon it became a routine treatment rather than a piece of experimental research.

To end on a personal note, I was flown to Cairo to convalesce at the famous 15th Scottish hospital, and finally the great day came to fly home. I had been promised a flight home in the morning at the transport office, but when I arrived at the airport at night I was told that two Russian war correspondents had arrived and had first priority. As I was going home on leave I was unimportant as far as the war effort was concerned. The next night I received a similar refusal, because two American flight sergeants, apparently the experts on the inner workings of a flying fortress, had to travel. On the third night I was refused because of a British stoker and a naval sub lieutenant. I thought this was perhaps a moment to "pull rank." The transport sergeant was very embarrassed and finally explained that both of these young men were due at Buckingham Palace next day, each to receive the Victoria Cross: they were the crew of a midget submarine. I was indeed proud to give way to them, and two days later I finally got a seat back to the United Kingdom. 